\title{
THE ROLE OF BUSINESS EDUCATION IN REPOSITIONING THE AILING GLOBAL ECONOMY CAUSED BY COVID-19 PANDEMIC
}

\author{
${ }^{1}$ PATRICK E. OCHE; ${ }^{2}$ OBETEN B. UKABI $\&{ }^{3}$ AKPUTU M. ODEY \\ Department of Vocational Education \\ University of Calabar, PMB 1115, Nigeria
}

Corresponding author’s Email: ukabiobeten@gmail.com - +2347034672244

\begin{abstract}
The sudden outbreak of covid-19 pandemic was indeed a phenomenal disaster that crippled the productive sectors and economic activities of nations. The incremental and consequential economic effects placed the global economy on a depressed position, as the world is presently witnessing the greatest economic recession and depression as never experienced in the economic history of the world. The overall aftermath was high business mortality rate, increasing rate of unemployment, reduction in, and irregular payment of workers salaries, high retrenchment of workers, increase in poverty lines leading to organized crimes, and sundry. However, the main thrust of this academic discourse was to examine the role of Business Education (BE) in repositioning the ailing global economy caused by covid-19, via review of related research literature. $B E$ as an academic programme is strategically positioned to inculcate the economic orientation, survival and functional skills necessary in raising the relevant manpower that will in turn serve as key drivers in the repositioning of global economy. In lieu of the above, this study explicates on conceptual clarifications, BE as economic survival strategy, and in global economic repositioning in covid-19 era, issues in $B E$ were also illuminated upon and a few recommendations made.
\end{abstract}

Key words: Ailing, Business Education, Covid-19, Global Economy and Repositioning. 


\section{Introduction}

The global economy has received a knockdown hit of covid-19 pandemic almost to a total collapse. Even to the point that the world's strongest economies are in a very bad shape today, not to talk of its far weighing effect on the lagging economy of third world nations like Nigeria. The total and partial lockdown periods of the pandemic affected nations because of the consequent lockdown in productive economic activities and sectors that resulted to a drastic converse effect on global economy (Di Mauro and Syverson, 2020). The situation had a rapidly downward economic retrogression effect. Consequently, most countries have eaten deep into their economic reserves, a lot of businesses at small, medium and large scale levels have been shut-down, there is high retrenchment of workers as never before in both public and private sectors of the global economy, reduction of workers' salaries, economic recession, hyper-inflation, high rate of unemployment and poverty lines, high level of organized crimes, high rate of illiteracy since the situation does not allow children of school age and adults to be enrolled in school programmes. To worsen the situation, countries are now adopting a "closed economic policies and restricting regulations" as a situational remedy or survival strategy (OECD, 2020a). Recent immigration policies of most nations are harsh and do not support foreign business and international partnership among nations because of the economic and health effects of the pandemic. Banking policies on international transaction platforms are crippled.

Accordingly, empirical evidence abounds on a World Bank global economic forecast for 2020 and 2021 respectively. "The forecast has it that global economic growth estimated that the global economic recession in 2020 will be the worst since World War II. It also estimated that the global economic recession would affect $90 \%$ of the world's economies, a percentage that is greater than what was experienced during the Great Depression. The World Bank's baseline estimate indicated that global economic growth could decline by $5.2 \%$ in 2020 and only partially recover in 2021 with $4.2 \%$ rate of growth, assuming that the global economy could begin recovering in the second half of 2020. In contrast, IMF forecasted a $4.9 \%$ rate of decline in 2020 and a recovery of growth to $5.4 \%$ in 2021. Similar to the OECD and the IMF forecasts, the World Bank argued that the economic impact of the global recession would fall most heavily on developing and emerging economies that rely on global trade, tourism, or remittances from abroad, and those that depend on commodity exports. In addition, the World Bank forecasted that most emerging and developing economies could experience rates of growth in 2020 that could be the lowest overall since 1960 s', with $90 \%$ of such economies expected to experience contractions in per capita incomes, and many millions of people are falling back into poverty" (OECD, 2020b).

It is with this consideration that this study is asking, what to be done to reposition the global economy? The study is also concerned about the type of education that is needed in a time such as this, to reposition the ailing global economy since education is the bedrock of any economic development. It is the light of this that the study advocates Business Education as a valid tool for repositioning the depressed global economy occasioned by Covid- 19 .

\section{Conceptual clarification}

For purposes of clarity, a few key concepts consist in this study will be explained.

Business Education as a global concept: Business education as an academic programme in the scheme of global education is viewed from two broad perspectives, which include "education 'for' business," which is aimed at equipping its recipients with the requisite 
attributes such as knowledge, skills, competencies, and attitudes to become gainfully employed in the world of work. The second aspect addresses "education 'about' business," which is aimed at providing a sound basis for further studies at the graduate and postgraduate levels (Adokpolor and Egbri, 2017). Illuminating from the two broad aspects of business education, the academic programme is structured globally to achieve a set of goals, these include to:

(i) Prepare students or clientele for specific career in office occupation;

(ii) Equip students with requisite skills for job creation and entrepreneurship; and

(iii) Expose students with necessary knowledge about business, including a good blend of computer technology, which incorporates information and communication technology (ICT).

In order to ensure effective implementation and realization of the aims and goals of business education, the curriculum according to Osuala (2009) is summarized into business knowledge and facts; business understanding; business skills and techniques; economic understanding; business attitudes; and business appreciation necessary to understand and adjust to that economic and social institution known as business. From the foregoing, business education can be considered as an economic oriented education that inculcate in the learner the knowledge and abilities to survive in the business world despite associated economic challenges.

On the other hand, to reposition according to Oxford Dictionary is to 'place in a different position; adjust or alter the position of something. Implying the idea in conceptualizing 'the repositioning of global ailing economy' could mean changing the bad position, or transforming the present global economic crisis caused by covid-19 pandemic into a better economic position. Considering the context relativity of the concepts, the role of business education in repositioning the ailing global economy is both strategic and indispensable.

\section{Business education as economic survival strategy in Covid-19 era}

The world around is in dare need of sustained economic survival strategies to cushion the depleting economic effects or consequences of the pandemic. The academic programme of business education is considered the best option as it provides its beneficiaries with the privilege and abilities to identify economic or business opportunities; it is education for the total survival of its recipients (economic survival strategy) for an economically versatile individual(s), who can cope in any given economic condition. This was the reason why the pandemic was viewed as an economic tragedy or misfortune to some, but to beneficiaries of business education, it was converted to fortunate business opportunities. They utilized their knowledge of business and economic understanding, business and techniques in exploring and taking advantage of the situation (Osuala, 2009). They identified and also maximized the business opportunities the pandemic presented in disguise; producing, selling and supplying of covid-19 protective and preventive equipment, products and services. The situation availed business opportunities in production, selling and supply of nose masks, hand sanitizers and gloves, temperature reading thermometers, online buying and selling, online mobile banking services, home delivery services, among others. Business education according to Asisafe, Bolarinwa and Edeh (2015) refers to a programme of instruction that offers various skills in accounting, marketing, and office technology and management. It is one of the occupational 
areas that are richly provided by vocational and technical education for the survival of individuals and nations.

Therefore, no academic programme can be a better option for repositioning the aiding global economy other than business education. The reason is simple, because generally education at all levels is considered as a major instrument for both national and global development. This is why education, and a more functional one in this context (business education) should be considered as a potent global force in repositioning the crashed global economy for the survival of nations. The covid-19 pandemic era has proven to all the nations of the world that the best economy that should be adopted and sustained in our ever changing world of today is the "knowledge-based economy." That which is based on economic invigoration and transformation resulting from the conversion of "knowledge" into economically viable assets. This indispensable role in the covid-19 era is what business education is structured to achieve if proper attention is given to it. In this sense, business education as a skilled-oriented educational programme for economic survival can be considered as the bedrock for the growth, progress, sustainability and repositioning of any nation's economy. It is a vital instrument for achieving sustainable economic survival (Ademiluyi, Bello and Akande, 2020).

Business Education is one of the core components of vocational and technical education which places emphasis on acquisition of survival skills and competencies for enhancement of economic empowerment, repositioning and sustainability (Ademiluyi, Bello and Akande, 2020). In his view, Oni (2015) stated emphatically that the subject of business education is a specialized vocational education that provides its recipients with skills, knowledge, attitudes, values and abilities needed to function optimally in the contemporary world, work and business. The versatile nature of this academic programme provides its beneficiaries the opportunity of surviving despite the retrogressive economic outcomes of covid-19. The year 2020 and part of 2021 has witnessed a sharp paradigm shift in job retention, security and sustainability of workers at all sectors of the global economy. A lot of employment uncertainties set-in that resulted to down-sizing of many workers (so many workers lost their jobs), leading to increase in unemployment levels of nations, poverty and untold hardship to individuals and households.

Undoubtedly, those affected by this ugly trend can set themselves up in business and wave-off the negative socio-economic consequences, if only they possess the versatile knowledge and survival skills of business through business education. It is a kind of education involving the inculcation of fundamentals, theories and processes of business to its clientele. Thus, business education should be considered as the right academic tool to remediate the crunch global economic consequences posed by covid-19. It is worthy of note, that although the world is experiencing economic meltdown with adverse impact on individuals, households, communities, countries and the global community caused by foreseen circumstances occasioned by covid-19 outbreak. The situation calls for a strategic deliberate investment in human capital and capacity development required for global economic repositioning and transformation. Because no economy can reposition itself without the human capital in possession of the appropriate economic knowledge for survival (Iniguez, 2011). This implies that for any economic repositioning to be made possible, there must be a timely, strategic, adaptable and sustainable human capacity development apt to addressing the problem it is designed to solve. To this end, appropriate educational programme must be carefully put in place to achieve the goal. That is the reason economic repositioning for empowerment is considered in terms of the development of mental and 
physical capacity, power or skills in individuals to enable them achieve enhanced social, cultural, political and economic status (Ajibodu, 2015), especially in surviving the challenging economic circumstances. Apparently, education of this sort is viewed as a tool for inculcating relevant survival and divergent skills required for economic revamping. Reiterating the above views, Awojobi (2016) averred that education is the best means to empower people, and that empowerment of people is an ineluctable means of achieving economic repositioning and survival by eradicating extreme poverty, reducing unemployment and end hunger.

\section{Business education in global economic repositioning in covid-19 era}

Business education as an integral part of the general education is seen as the bedrock of growth, progress, sustainability and economic repositioning of nations (Ademiluyi, Bello and Akande, 2020). Emphasis on establishment of entrepreneurial or small scale businesses and skills acquisition for self-reliance, and to stay afloat of the consequences of depressed economy is a notable global economic campaign and trend today. The degree of this campaign by development agencies, social institutions and the society at large have caused a lot of youths and adults alike to make hasty decisions in venturing into businesses they have no, or inadequate knowledge, requisite skills, experience and education required to succeed. Planning and managing for unforeseen circumstances, otherwise known as risk management and other business skills like management skills, accounting skills, marketing skills, in business education terms are vital knowledge and skills that business education offers to its recipients that equips them to manage the inevitable but calculable risks associated with business, for successful business operations. This knowledge and skills are essentially applicable to all forms of business concerns and establishments regardless of size, scale and environment it operates.

Conversely, Omotola cited in Ukabi (2018) informs that most SMEs in some parts of the world have not been able to function optimally because they are challenged with poor management practices, poor accounting standards, adoption of appropriate risk management strategies, shortage of skilled manpower, poor business strategies, lack of ICT skills, lack of financial discipline. It is a common feature of most SMEs to ignore basic business skills, and therefore flaw some indispensable principles of running a successful business. It is commonly said that "business is risk-taking" better put in technical business terms, we can say that "business is "calculated risk-taking." During the Covid-19 era, a lot of businesses especially small scale businesses were adversely affected, most of them folded-up while some that are still in operation are in bad shape and highly indebted. Reasons for such pronounced impact may not be far from the fact that the owner-managers and operators of such businesses lack business knowledge and skills that are required to effectively and efficiently manage and provide insurance coverage for their businesses. Supporting this view, Duruamaku-Dim (2017) acknowledged that the success or failure of any business organization or institution lies on the management or administration of the organization or institution. Thus, business education as an academic programme that provides varied skills in accounting, management, marketing, ICT, office technology and management is considered as an essential tool to be utilized in repositioning entrepreneurial businesses that serves as major economic drivers of the global economy. Any business that does not have a strategic and realistic risk management plan is a potential failure especially in an ever changing business world of today. It does not matter how well the business may be performing at a moment, because today's business environment is flexible to the changes in the global society which mounts incredible pressures on the productive sectors of the economy. 
Succinctly, business education plays inevitable roles in the repositioning of the global economic crises which is caused by the pandemic; by providing jobs for the jobless and those laid-off from their jobs, reduction in poverty lines, and establishment of self-reliant ventures and employment of labour, increases revenue generation for public income. Therefore, effective business education with its vocational and entrepreneurial oriented packages can be utilized by individuals, households, communities, government and non-governmental organizations and agencies, to achieve human capacity development for resource optimization as a means of achieving strategic and sustained economic development at all levels. Thus, Ekpoh and Edet (2011) justifies that business education given its entrepreneurial orientation involves the inculcation of qualities and skills needed by individuals to function effectively in the dynamic world of business, which is a strong indices of economic repositioning. ABEN (2017) reiterated that business education enables an individual to acquire the knowledge and saleable skills needed to function effectively in the world of business and become a responsible or worthy member of the society. To Okafor (2013), business education as an academic programme intended for achieving socio-economic empowerment, advancement and development of those who benefit from it can serve the good purpose of economic diversification and repositioning.

Aladenusi and Ayodele (2012) posited that education, especially business education is the spring board for societal and global development, as it brings about substantial and meaningful changes. Consolidating on the above views, Adegbeson (2011) stressed that people and nations are what they are because of the type and nature of education they are exposed to. He advised that to be able to reposition the ailing global economy, the type of education that should be adopted should have the capacity of making countries of the world to have a steady supply of highly creative and innovative citizens who will help to keep improving the living conditions of the general citizenry, and to solve the existential problems that emerges at different times. Predominantly, such education must be the type that inculcates proficient knowledge and skills in ICT, considering the prominent role ICT plays during the pandemic. It is true that most workers in both public and private sectors of the economy that were not relinquished of their jobs during the covid-19 lockdown were those who possess a good and versatile knowledge and skills in ICT, because they were able to still perform their jobs and hold official meetings at the comfort of their homes via the internet, social media platforms, and other ICT networks like zoom. Businesses and business operators that lack ICT skills and operations surrendered to those who possess the knowledge and skills, and it was an added advantage to them (Ali, Haolader and Muhammad, 2013). However, one among the global set goals of business education as stated earlier is to expose its beneficiaries, with the necessary knowledge about business, including a good blend of skills in computer technology for information and communication technology (ICT). This aspect of the academic programme is an added advantage to those who benefit from the programme, especially when harnessed with other business skills acquired through business education, it avails one the opportunity of having an edge over the present prevailing economic challenges. The ICT skills acquired will enable one to explore and maximize the online business opportunities, and to do business and other profitable economic related activities (Omariba, 2012).

Apparently, the world would have been a completely shut-down system during the pandemic if not for the knowledge and utilization of ICT in all spheres of life; education, business, banking, medicine, communication, and sundry. Therefore, in an era of severe global economic crises caused by covid-19 pandemic, business education offering of ICT 
knowledge and skills combined with the knowledge of business and economic understanding will help individuals who benefit from it to stay afloat, establish viable and sustainable businesses for self-reliance, create sustainable and inclusive jobs leading to reduction of unemployment and poverty lines, among other benefits. This also calls for attention to be given to improve the status of the academic programme in order to carter for the high-dropout from school cases, those sacked from jobs that were their only source of livelihood and their families, and those who are unemployed in the society. This can be achieved by adopting both the formal and informal aspects of the programme to train and retrain those who will benefit from it.

\section{Issues in utilizing business education for global economic repositioning in Covid-19 era}

The academic programme of Business Education plays a prominent role in global economic transformation, but not without impediments. The programme is faced with several issues that impedeits effectiveness and the extent of utilization in most countries of the world for economic juxtaposition and improvement. Some of these issues will be identified and examined to ensure effective implementation and utilization of business education for global economic repositioning.

\section{Issue of Fiscal policies}

This issue is concerned with both the political and economic challenges confronting effective implementation of business education. The attitude of political leaders in formulating policies that concern education in most countries impedes its implementation and effectiveness. A good example is the instance of Nigeria where less than $10 \%$ budgetary allocation is annually apportioned to education sector which is far less than the approved percentage by the United Nations. The outcome of this epileptic budgetary allocation to education has far weighing consequences of poor funding of the programme. Business Education as an integral part of vocational education that requires modern machines, facilities, skilled manpower and a functional environment for effective teaching, learning and acquisition of skills, is in nature a capital intensive programme. But in a situation where those in the political class fail to make favourable funding policies that are supported with corresponding funding actions, becomes a major impediment since every other aspects of its implementation depends largely on the extent of funding (Rumanyika and Galan, 2015).

\section{Issues with new trends in capacity or faculty development}

Human capital or faculty development is considered indispensable in the programme implementation and as a tool for achieving global economic repositioning, because it serves as the major driver of other component resources for social change and economic development. In most departments and units of business education there is lack of, or shortage of competent staff in possession of appropriate knowledge, attitude and functional skills to man the programme. This becomes a crucial issue as the quality of learners (students) produced and sent into the society, is a direct function of the quality of teachers. Therefore, the competence of business educators and their continuous capacity development is inevitably significant in raising graduates or school leaders who are adequately equipped and prepared to survive and proffer solutions in the world of work and business. This is why teachers' professional training and retraining should be emphasized in countries educational policies and implementation. 


\section{Issues with adoption of ICT in teaching and learning of business education}

The advent of ICT gadgets in teaching and learning instruction makes imperative demand on business teachers to be re-tooled for easy utilization of ICT facilities in the teaching and learning of business processes. This is imperative because without ICT literacy, business educators would not be able to use ICTs for effective instructional delivery, and at the same time lack the ability to impact the skills on the learners. Observation has shown that most business educators especially in the third world nations do not have the knowledge of ICT, talk-less of using it to impart knowledge and skills on those they teach. This is a clear indication why a greater number of business education students and graduates are found wanting in a world classified as a digital world, where most of the business activities require online skills and presence. The lack of these skills can render individuals who claim to be benefactors of business education incapacitated of utilizing the online business and economic opportunities presented by the pandemic. The incorporation of new technology into the teaching and learning experiences of business education is an essential element in improving on the learning gains and subsequent opportunities in the world of work and business (Avolic, Benzaquen and Pretell, 2019).

\section{The changing needs of students in a changing world}

The assertion that "change is the most permanent thing" also applies here. There are major societal paradigm shifts in learners' expectations as a result of globalization and technological advancement in recent times. The demand for business education is increasingly a global phenomenon, hence, the profile of students has also changed drastically and significantly. Business education students today need the kind of training that would make them versatile and competent in a wide range of careers; engineering, economist, educators, pharmacist, accountants, managers and administrators, agriculture, catering, tourism, marketing, among others from all over the word. They want a rich business education content that can offer them the opportunity of participating in global problem-solving. This student's expectation is quite challenging and requires considerable steps in achieving them since the world is constantly changing with thought provoking emerging trends, business education in the world of today need new learning experience and more rounded and integrated form of education. To achieve this, the programme must be relevant to the needs and aspirations of the learner and the society at large. This also calls for modern facilities, innovative and creative faculties and instructional strategies. But what is operational in most part of the world is still the traditional form of business education that does not have the capacity of achieving the new aspiration of learners for global economic impact and competitive advantage.

\section{Issues with curriculum review}

Challenges posed by the novel pandemic in global economy calls for an urgent review of business education, if the programme must be positioned as a tool for achieving global economic repositioning. Innovation in business education in recent times had mainly focused on the architecture of programmes, the contents and teaching strategies. As a result of the maximum requirements on business education programme content in the new covid-19 era, business schools are to come to a point of decision where they need to ask of the value and relevance of the content in relation with the present global economic needs. Hence, business education curriculum need a critical examination and overhauling of the traditional curriculum still in use in most countries, in order to incorporate the new trends in the global economy to it for relevance in the new scheme of global economic events. Any curriculum that does not undergo consistent re-evaluation and reviews in the ever changing society today 
is considered obsolete or outdated, and cannot be relevant in training world class individuals that can match-up with new economic trends in the world. Therefore in considering business education as the appropriate academic tool for global economic repositioning during the economic crises of covid-19, there is an urgent need for curriculum review, in order to include relevant curriculum contents for imparting the right knowledge for economic repositioning.

\section{Conclusion}

The depleting economic outcry in our world today as a result of the sudden outbreak of covid-19 pandemic resulted in a lot of deaths, high business mortality rate, a sharp downplay in most economic activities, and consequent retrenchment of workers in both public and private sectors of the economy. The situation calls for an economically oriented and empowering form of education since education is an instrument for inclusive development. Thus, business education programme which is an integral component of vocational education with the mission of inculcating in learners various survival skills in functional economic area such as accounting, marketing, management, office technology and management is considered to be a relevant tool in repositioning the ailing global economy caused by the pandemic, if efforts would be made to improve on its content and implementation strategies in relation to the global economic changes. Therefore, the study gives insight on the concept of business education, its global aims and objectives, broad curriculum content, business education as an economic survival strategy, business education in global economic repositioning and issues in utilizing business education for global economic repositioning in covid-19 era. The study made a few useful recommendations in terms of steps that can be taken to improve on some of the identified issues examined, in order to effectively realize the goal of invigorating business education as a vital tool for achieving global economic repositioning.

\section{Recommendations}

The following recommendations are made due to the discourse above:

1. Political administrators of nations should see education as an essential sector and worthwhile investment that serves as a catalyst to all other forms of development, and then increase the budget allocation for education. There should also be a comprehensive cooperate funding synergy between public and private sectors in order to improve the funding of business education.

2. There should be a consistent and integrated global platform for capacity development programmes for business educators. This can be done by forming an international regulatory body to establish international guidelines that stipulate business teachers' professional minimum standards and best practices to ensure quality control and assurance at all levels. International exchange programmes for business teachers should be designed by the same international body and made compulsory for all business educators at all levels.

3. There should be adequate provision of modern ICT facilities in business education resource centres, computer rooms and classrooms to enhance the teaching and learning of ICT skills among teachers and students of business education. There should be both short-term training and retraining packages for teachers to enhance their ICT skills and onward utilization for pedagogical purposes. This would help the 
teachers to keep abreast of new innovations in ICT based instructions and further inculcation of the skills to learners.

4. The learners' needs and aspirations should form a key consideration for selection of curriculum items and reviews, and the basis for organizing and adopting of new learning experiences and strategies to improve the teaching and learning of business education for varied career prospects.

5. Business schools should institute academic extension programmes for community development. Community approaches to business education should be adopted for inclusive and sustainable training and development of community members. To achieve this, business schools should structure scratch and distance learning programmes with the intention of imparting community members with the relevant business skills to survive in changing world of work and business. 


\section{References}

Adegbeson, S.O. (2011). Establishing quality assurance in Nigerian education system: Implication for educational manager. Educational Research and reviews 6(2): 147151.

Ademiluyi, A. B., Bello, G. A. \& Akande, R. A. (2020). Strategies for optimizing business education as an instrument of economic empowerment and sustainable development in Nigeria. Africa Journal of Technical and Vocational Education and Training, 5(1), $52-65$.

Ajibodu, S. A. (2015). Strategies for improving business education in a globalized society. Book of Readings 3(4): 53-64.

Ajisafe, O. E., Bolarinwa, K. O. \& Edeh, T. (2015). Issues in business education programme: challenges to national transformation. Journal of Education and Practice, 6(21): 208212.

Aladenusi, O. \& Ayodele K. O. (2012). Leadership education as a veritable tool for good governance and democratic development, an empirical assessment of Public perception. American Journal of Educational Research, 6(3): 210-213.

Ali, G., Haolader, F. A., \& Muhammad, K. (2013). The role of ICT to make teachinglearning effective in higher institutions of learning in Uganda. International Journal of Innovative Research in Science, Engineering and Technology, 2(8): 61-73.

Association of Business Educators of Nigeria, (ABEN) (2017). Mandate of Business Education in Nigeria. Ilorin: Integrity Publication.

Avolio, B. E., Benzaquen, J. B. \& Pretell, C. (2019). Global challenges for business education and the new educational agenda: Graduate attributes and teaching methods. E-Journal of Business Education and Scholarship Teaching, 13(2): 80-99.

Awojobi, A. (2016). The Role of Business Education in a Developing Economy. Business Education Journal, 5(3): 38-47.

Di Mauro, F. \& Syverson, C. (2020). The covid crisis and productivity growth, VOX, CEPR policy portal. Available online at: https//:voxeu.org/article/covid/covid-crisis-andproductivity-growth?utm source=dlvr.it\&utm medium=twitter. Accessed on March 23, 2021.

Duruamaku-Dim, G. C. E. (2017). Nascent models, theories and management education: A score card of productivity. Abuja-Nigeria: Infinity Media.

Edokpolor, J. E. \& Egbri, J. N. (2017). Business education in Nigeria for value re-orientation. Abuja: Infinity Publishers.

Ekpoh, U. I., \& Edet, A. O. (2011). Entrepreneurship education and career intentions of tertiary education students in Akwa Ibom and Cross River States. International Education Studies, 4(1): 1913-9020.

Iniguez, S. (2011). The learning curve: How business schools are re-inventing education. In B. Kathuria, and C. K. Weidener (ed.) Experiential learning process: Exploring 
teaching and learning of strategic framework through the winter survival exercise. Journal of Management Education, 29(5): 672-695.

OECD (2020a). OECD economic outlook. Paris: OECD Publishing.

OECD (2020b). Statistical insights: Small, medium and vulnerable. Paris: OECD Publishing.

Okafor, A. (2013). Practice of entrepreneurship. Lagos. Legacy Publications Ltd.

Omariba, A. (2012). Preparedness in integrating information communication technology in training teachers in public primary teachers' training college in central region, Kenya. Unpublished Doctoral thesis submitted to Department of Educational Technology, School of Education Kenya University.

Oni, D. T. (2015). Poverty reduction through entrepreneurship. Journal of Social Sciences and Humanities, 2(2): 14-26.

Osuala, E. C. (2009). Business and Computer Education. Enugu, Nigeria: Cheston Agency Ltd.

Rumanyika, J. D. \& Galand, R. M. (2015). Challenges for teaching and learning information and communication technology courses in higher learning institutions. Journal of information and Knowledge Management, 5(2), 1-12.

Ukabi, O. B. (2018). Entrepreneurial skills required for improvement of small business enterprises in Calabar Metropolis of Cross River State. Unpublished thesis submitted to graduate school University of Calabar.

UNCTAD (2020). World investment report 2020: International production beyond the pandemic. Geneva: United Nations Publication. 